\title{
The Opinions and Approaches of Slovak Youth on Migration and Human Rights (Minireview)
}

J. Pavelkova (Jaroslava Pavelkova), M. Mojtova (Martina Mojtova)

Constantine the Philosopher University in Nitra, Faculty of Social

Original Article

Sciences and Health Care, Department of Social Work and Social Sciences, Nitra, SK

\section{E-mail address:}

jaryk@post.cz

\section{Reprint address:}

Jaroslava Pavelkova

Constantine the Philosopher University in Nitra

Faculty of Social Sciences and Health Care

Department of Social Work and Social Sciences

Kraskova 1

94974 Nitra

SK

Source: Clinical Social Work and Health Intervention

Volume: 9

Issue: 2

Pages: $81-86$

Cited references: 7

\section{Reviewers:}

Gabriela Lezcano

University of California, San Francisco, USA

Piotr Nowakovski

Warsaw Management University, PL

\section{Key words:}

Human rights. Migration. Multiculturalism. Social integration. Youth. Slovakia.

\section{Publisher:}

International Society of Applied Preventive Medicine i-gap

CSWHI 2018; 9(2): 81 - 86; DOI 10.22359/cswhi_9_2_12 @ 2018 Clinical Social Work and Health Intervention

\section{Abstract:}

The contribution is devoted to the worsening level of human rights on the basis of global events closely related to large area migration that interferes with the whole world and brings about disruption of people's coexistence in a postmodern multicultural society in Europe. The phenomenon of population migration for the purpose of social integration 
is currently one of the most problematic areas of international relations and politics. This fact has its consequences in the society of EU in the cultural, social, political and economic spheres. The aim of the work is to present the opinions and attitudes of Slovak youth on migration and issues related to the concept of integration foreigners in the territory of the Slovak Republic.

\section{Introduction}

At present, the level of human rights is deteriorating on the basis of global events (fundamental freedoms such as expression or assembly). From the US Department of State's Annual Report on the human rights situation in the world (2017), it follows that both the Czech and the Slovak Republic have a negative attitude towards immigrants to which some statements of politicians have contributed. The document states, that the Czech Republic continues to face social discrimination against Roma; stigmatization of HIV-infected people; reluctance to provide asylum for migrants; or corruption. The Annual Report, which is based not only on 2016 data but also on the events of 2015, marks the Czech political system as a stabilized pluralist democracy where armed and security forces are under effective control of civilian offices. Washington criticizes the problem of integrating a numerous Roma minority. The United States sees the Roma's inadequate involvement in political life even though there are Roma parties in the country. The report mentions that no Roma are sitting in Parliament, Government or the Highest Judicial Court: Roma candidates have failed even in regional elections. The seriousness of social exclusion is illustrated by the report, for example, by the extension of so-called excluded localities and ghettos, where one third of Roma live. The Americans also noted that a high number of Roma children attended special primary schools in which a segregated educational system was created specially for them (https://www.novinky. cz/zahranicni/amerika/431268-americka-diplomacie-kritizuje-cr-kvuli-diskriminaci-romu-nechuti-k-migrantum-a-korupci. html). Criticism expresses even the attitudes towards migrants. The Czech Republic is also the target of criticism because of overcrowded prisons and lengthy detention of migrants and asylum seekers in detention centers (increasing the number of hateful speech against migration).

It is not possible to agree with the cited sentences. The events in society after 1989 brought revolutionary changes in the political and economic systems, which affected every citizen in Czechoslovakia. This fundamental qualitative transformation of social order has subsequently manifested itself in the management of various areas of the economy, but also the understanding of public and political consideration of the different needs of ethnic minorities; the creation of respect and a friendly environment for minorities; the promotion of the view that ethnic diversity is the enrichment of society and people must be equal before the law; although laws may reflect the ethnic groups autonomy only to a certain extent. Fundamental values must protect the law of the state universally, and the liberal democratic society should principally build on the equal representation of all persons. Fundamental values must protect the law of the state universally, and the liberal democratic society should be principally built on the equal representation of all persons (Matousek 2008). Both Czech and Slovak Republic 
respect the Convention for the Protection of Human Rights and Fundamental Freedoms as the most important human rights treaty negotiated within the framework of the Council of Europe (1992) which is the basis of regional international human rights protection in Europe (https://www.e-justice. europa.eu/content fundamental_rights176-cs.do). Migration is a natural part of all human history. Numerous war conflicts, fear of persecution, economic and social differences between countries, regions, or even continents, as well as the process of globalization of the economy, development of information technologies, etc., constantly are increasing its intensity. Migration also brings social, cultural, social, political and economic consequences. Migration affects the composition of the population by age and gender; between emigrants are usually dominated young men, thus the emigration areas are losing all the most productive component of population (Rolny \& Lacina 2001).

Rapid scientific and technological development; expansion in the service sectors; socio-economic and political developments in the various regions of the world; and the above-mentioned global-ization; and many other processes are a source of wide-spread migration to the developed European countries. The public and the political leadership of the countries of the European Union are deeply divided on the acceptance or refusal of the authorities' access to refugees (legal and illegal). The massive rise of migration may also threaten the traditional orientation of society to Western democratic values. The main immigration countries are Germany, Italy, France, The Netherlands, Switzerland, Austria, Belgium, Spain, the Nordic countries of Europe (post-communist countries become, for most of them, only a transit country). At present, on the basis of the continuing migratory flows of refugees and their social integration to society (2017), is one of the highly topical tasks of the state administration.

"On the other hand, uncontrolled migration, the company noted, may have a negative impact on the company, as it has repeatedly proven in history. Unprepared and unpredictable migration can disintegrate the entire society," warned the Archbishop of Prague and the President of the Czech Bishops' Conference Dominik Duke (www. novinky.cz/zahranicni/evropa/429987-nekontrolovana-migrace-muze-spolecnost-poznamenat-varoval arcibiskup-duka. html).

\section{Approaches of Slovak youth towards foreigners}

The Slovak Republic is used as a transit country for the current migration wave. It has no economic or technical potential to enable thousands of refugees to secure the conditions for a dignified life and gradual integration into society (Pavelkova 2016). The aim of migration policy in Slovakia is to ensure, first and foremost, the protection of our own interests; implementation of the stated objectives and priorities in the area of migration policy; compliance of state regulations with EU regulations; actively participate in law-making with the EU in the context of migration policy.

In the context of this issue, we would like to present the results of the quantitative research carried out in 2016 (data through questionnaire), with a view to analyzing the attitudes of young people of primary, secondary and university educational institutions in the field of migration, asylum and integration of applicants asylum in Slovakia (Hornacek 2016). The aim of the research was to introduce the attitudes of Slovak youth towards migration and issues related to the concept of integration of foreigners in 
the territory of the Slovak Republic. Attention was also paid to whether young people are considering pro-socially and are willing to help foreigners in an unfavorable life situation without benefiting from it. The research sample was made up of the young at primary and secondary school (Hrnciarovce nad Parnou, 60 respondents; Rakovice, 60 respondents and the Faculty of Social Sciences UCM in Trnava 60 respondents.

\section{The research revealed interesting results (Hornacek 2016, 82-84)}

To find out whether students know the terms migration and asylum, the respondents confirmed that these terms are not foreign to them as evidenced by more than 138 respondents $(70.0 \%)$. Pupils and students have already met with these words which can be assumed as the issue is currently being publicized.

Because integration into society is important to each individual due to inter-human relations, we were interested in whether the respondents were happy to meet new people. 179 respondents $(99.4 \%)$ are happy to meet new people. Communication is important during meeting new people. As foreigners often do not speak the Slovak language, we asked whether the communication was demanding for the respondents. $115(64.0 \%)$ said that communication is not a problem for them.

Migration itself is a challenging process for people. Leaving home, family, friends and adapting to the new environment can affect the individual stressfully in many cases. We asked whether they can imagine, they would find themselves living in another country. $106(58.8 \%)$ said positively. It is important however to distinguish voluntary departure from the country, and whether an individual is forced to leave. We asked the respondents, whether it is the correct solution to leave the country. $90(50.0 \%)$ said that leaving is not the right solution. 55 (30.6\%) answered it depends on the circumstances. We can say that respondents disapprove the migration of citizens to Europe.

71 respondents $(39.6 \%)$ responded to the question whether they agreed yes. to the admission of migrants by the Slovak Republic. On this issue, however, the unanimous decision cannot be observed among respondents, whereas 61 (33.8\%) did not think about this problem and 48 (26.6\%) disagree with the admission of migrants.

State authorities and non-governmental organizations provide operable help to foreigners on Slovak territory. We are surprised if respondents know about some organizations that provide this help. Respondents' answers to the three options had almost the same number percent. 69 (38.3\%) said they did not know about these organizations. We can say that there is weak marketing in Slovakia in the promotion of these organizations which deal with the solved problem. The ever-increasing migratory waves to Europe are a stimulus to an awareness, that it is a serious phenomenon that cannot be ignored.

Each society has its deep rooted customs and traditions. Foreigners who come into the majority society of the country, brings with them the own. On the question whether foreigners should respect the customs and traditions of the majority groups, 127 of them $(70.7 \%)$ said yes. The result is that for the better integration of foreigners it is essential to respect the traditions and customs of the majority society.

Every society is in fear of the current mass migratory waves pouring to Europe. The media conveys daily negative information about migration; every society creates 
prejudices. Student respondents were asked whether they think society is biased against foreigners. 95 (59.9\%) said yes. Of half of those surveyed it can be stated that society is full of fears and prejudices. It is possible to wonder, where increasingly in the world terrorist attacks carried out by radical members of the Islamic religious congregations are directed toward citizens.

Since often migrants were of the Islamic religion we were interested in what opinion respondents have of this religion. $88(49.0 \%)$ said they had a neutral view to Islamic religion. Interestingly, however, respondents' responses are similar. 46 (25.0\%) had a negative and, equally, 46 $(25.0 \%)$ a positive opinion.

As the issue of migration needs to be addressed, our Questionnaire survey tried to find out what respondents see as the biggest shortcomings in solving the migration problem. Based on the results, we can say, that 92 respondents $(51.0 \%)$ agreed that the biggest problem is financial support. The Slovak Republic, as well as other V4 states, is not technically and financially prepared to accept and secure the quality of life of migrants coming to Europe (Hornacek 2016).

Based on the stated objective of analyzing the views of pupils and students of primary, secondary schools and university concerning migration, asylum and integration in the Slovak Republic, we found that respondents are fully aware of the seriousness of the situation of migration and the issue is of interest to them. It is important to take into account the views of the students because they themselves are the future of the country. In the curriculum, it would be useful to extend information to help students reduce their prejudices. Information available on social networks or in the media is often distorted, biased, and is aimed at creating a false image of real reality. Concerns about Islamization and terrorist attacks prevailed among more respondents. Students perceive the problem even in solving the migration process. They are of the opinion that EU borders should be closed and entry into this territory should be controlled. Improving communication in a foreign language would help to remove barriers and prejudices.

\section{Conclusion}

At present, cultural habits and society are changing faster than before; traveling is easier and more accessible to many of us; new technologies allow faster and permanent communication not only between us, members of the majority but also between migrants. It is important for the society to have information about migration. Knowledge of this entity must become part of the socialization of the individual in the form of compulsory multicultural education as the development of self-understanding of the pupils themselves and the values of their culture, including the focus on knowledge and understanding cultural differences between people of all backgrounds, interpersonal relationships, intercultural communication and adaptation to life in multicultural society, respect, tolerance and solidarity to ensure the coexistence of different cultures on the European continent. Just respecting the Convention on the Protection of Human Rights and Fundamental Freedoms in practical life as the most important human rights conventions agreed within the Council of Europe (1992) can be a way of achieving understanding and coexistence at present.

\section{References}

1. HORNACEK F (2016) Migration and its Social Dimension (Master's Thesis). Trnava: FSV UCM. (Slovak).

2. MATOUSEK O (2008) Dictionary of Social Work. Praha. Portal. 272 p. (Czech). 
3. PAVELKOVA J (2016) V4 in Relation to the "Coalition of the Willing" Countries of the European Union. In: Mackinova M, Editor. Migration and its impact on V4 countries. Proceedings of International Conference; Trnava: Faculty of Social Sciences UCM. p. 136-147.

4. ROLNY I, LACINA L (2001) Globalization-Ethics-Economics. Boskovice. Albert. 256 p. (Czech).

5. Article in an online periodical: Novinky. CTK (2017). US diplomacy criticizes the Czech Republic for discrimination of Roma, dislike of migration and corruption. Novinky.CZ [online] [cit.2017-10-23]. Available from: https://www.novinky.cz/ zahranicni/amerika/431268-americka-diplomacie-kritizuje-cr-kvuli-diskriminaci-romu-nechuti-k-migrantumakorupci. html (Czech).
6. Article in an online periodical: Novinky. CTK (2017) Uncontrolled migration can stigmatize society, warned Archbishop Duke]. Novinky.CZ [online] [cit. 201710-23]. Available from: https://www. novinky.cz/zahranicni/evropa/429987-nekontrolovana-migrace-muzespolecnost-poznamenat-varoval-arcibiskup-duka (Czech).

7. Link / URL World Wide Web (WWW) Sites: The Convention for the Protection of Human Rights and Fundamental Freedoms, as the most important human rights convention agreed within the Council of Europe, is the basis for regional international human rights protection in Europe] [online]. 1992 [cit. 2017-05-14]. Available from: https:// www.e-justice.europa.eu/content_fundamental_rights-176-cs.do (Czech). 